\title{
STRATEGI BACA PUISI BAHASA INDONESIA DAN INGGRIS BAGI GURU-GURU DAN SISWA DI SDN 65 PEKANBARU DAN 63 PEKANBARU
}

\author{
Junaidi*Mohd. Fauzi, ** Qori Islami*** \\ Jurusan sastra Inggris dan Sastra Indonesia \\ Fakultas Ilmu Budaya, Universitas lancang Kuning, Pekanbaru \\ drjunaidi@yahoo.com
}

\begin{abstract}
Ringkasan
Judul pengabdian masyarakat ini adalah Strategi Baca Puisi Bahasa Indonesia dan Inggris bagi Guru-guru dan Siswa di SDN 65 dan Pekanbaru dan 63 Pekanbaru. Tujuan pengabdian ini adalah untuk memberikan pemahaman tentang strategi baca puisi Bahasa Inggris dan Bahasa Indonesia. Pelaksanaan baca puisi selama ini belum maksimal oleh kebanyakan pendidik dan juga siswa.. IbM ini bertujuan untuk meningkatkan kemampuan guru-guru dan siswa sekolah dasar dalam strategi baca puisi kedua bahasa. Metode yang digunakan adalah ceramah dan praktek. Hasil pengabdian menunjukkkan bahwa guru damemperoleh strategi baca puisi bahasa Inggris dan Indnesia.
\end{abstract}

Kata Kunci: Strategi baca puisi, pelatihan, guru dan siswa

\begin{abstract}
The title of this social services is the Strategy of Reading poetry English and Indonesian for teachers and students of State Elementary School 65 Pekanbaru and State Elementary School 63 Pekanbaru. The purpose of the program is to socialize the use of Strategy which is still not maximally used by most of teachers and students. This program is conducted to increase the abily of elementary school teachers and students in reading poetry. The method used in this program is describing and practice. The result of the program shown that teachers and students understand the program.
\end{abstract}

Keywords: Reading poetry strategy, Social service, teachers and students

\section{A. PENDAHULUAN}

Aktifitas membaca puisi di sekolah-sekolah saat ini sudah sangat kurang dan cendrung kurang diminati. Merosotnya aktifitas baca puisi di sekolah karena apresiasi terhadap puisi itu sendiri juga masih lemah. Apresiasi puisi dimaksud meliputi perbincangan-perbincangan, kritik-kritik terhadap puisi, dan penulisan-penulisan esay terkait puisi.

Berbagai komunitas puisi berupaya terus mengembangkan dan mengapresiasi penggiat puisi dengan menyelenggarakan kegiatan baca puisi tingkat lokal maupun 
nasional, seminar dan anugerah puisi. Para Sastrawan, jurnalis dan para penggiat puisi di Provinsi Riau sering menyelenggarakan kegiatan yang berhubungan dengan puisi, demikian juga para akademisi yang memiliki minat besar dalam puisi terus mengadakan kegiatan-kegitan serupa. Kegiatan-kegiatan tersebut ternyata belum sepenuhnya menyentuh akar rumput yang diharapkan. Akar rumput yang dimaksud adalah anakanak usia sekolah tidak tampak secara signifikan kiprahnya dalam puisi. Yang tampak adalah mereka lebih menyukai program-program budaya populer seperti Gadget, games, atau kegiatan lain yang kurang bermanfaat.

Kegiatan dalam membaca dan menikmati puisi sesungguhnya memiliki nilai positif bagi generasi muda. Setidaknya ada dua hal yang bisa didapatkan oleh pendengar ddan penikmat puisi. Pertama, hiburan, yakni akan mendapatkan keindahan dan kesenangan dengan menikmati puisi yang di baca. Karena puisi disusun dengan untaian kata-kata pilihan, indah dan mempesona. Kedua, pembaca maupun penikmat puisi akan mendapatkan nilai-nilai edukasi, karena penulis puisi pastilah mempunyai tujuan-tujuan mulia ketika menulisnya. Pesan tersebut hendak disampaikannya dengan kata-kata kiasan dan kata-kata pilihan sehingga maksudnya akan dipahami secara mendalam.

Wordsworth mempunyai gagasan bahwa puisi adalah pernyataan perasaan yang imajinatif, yaitu perasaan yang direkakan atau diangankan. Adapun Auden mengemukakan bahwa puisi itu lebih merupakan pernyataan perasaan yang bercampurbaur. Wordsworth selnajutnya mengatakan bahwa Poetry is the best words in the best order.

Pembelajaran bahasa Inggris juga dapat dilakukan dengan aktifitas membaca dan menganalisis puisi-puisi Inggris. Disadari atau tidak, membaca puisi bahasa inggris bermanfaat sekali untuk meningkatkan kemampuan berbahasa seseorang. Pemahaman mengenai informasi yang disampaikan oleh pembuatnya, kemudian mengenali pengucapan dan intonasi bisa meninggikan kualitas berbahasa. Didalam puisi terdapat unsur-unsur seperti diksi, imagi, kata konkret dan bahasa figuratif. Unsur-unsur inilah yang bisa menjadi bahan pembelajaran yang bermanfaat untuk Anda. 
Banyak manfaat mengajarkan puisi kepada siswa, diantaranya adalah:

\section{Mengajarkan Dalam Memilih Kata Yang Tepat}

Dalam mengkomunikasikan sesuatu, Anda tentu tidak ingin bila seseorang salah tanggap dengan apa yang Anda bicarakan. Diksi atau pemilihan kata yang tepat menjadi pembelajaran yang tepat. Memilih kata yang tepat yang sesuai dengan makna dan keselarasan bunyi sangatlah penting, dan Anda bisa mendapatkannya didalam puisi.

\section{Mengajarkan Susunan Kata Yang Benar}

Membaca puisi bahasa inggris ini dapat mengantarkan seserang dalam memahami susunan kata yang sesuai. Susunan kata yang digunakan penyair dihubungkan dengan pengalaman indrawi misalnya penglihatan, pendengaran dan lain sebagainya.

Susunan kata yang dihubungkan dengan indrawi ini akan bisa Anda rasakan seolah-olah seseorang mengalaminya. Hal ini mengantarkan Anda jauh kedalam perasaan yang mana bisa mengungkapkan perasaan dengan kata-kata yang lebih indah.

Jika dihubungkan dengan pembelajaran bahasa inggris, maka hal ini lebih mengedepankan bagaimana mengungkapkan perasaan dengan kata. Sebagai contoh, mungkin Anda menyimpan perasaan, entah apa itu, dan ingin mengungkapkannya namun belum mampu. Disinilah, seseorang bisa mempelajarinya terkait bagaimana mencetuskan ungkapan dalam sebuah susunan kata yang baik dan bisa difahami oleh orang lain.

\section{B. Tinjauan Pustaka}

Dalam puisi, banyak bahasa figuratif yang mana ditujukan untuk sesuatu hal dalam arti yang sebenarnya. Maksud dari kata-kata yang disusun tentulah mewakili perasaan dari penyair, bahkan juga sebagai sebuah kata yang berisikan nasehat atau amanat dan semacamnya.

Kata-kata kiasan ini tentu bakal membuat Anda lebih peka dalam menggunakan bahasa. Bahkan memahami apa yang sebenarnya diinginkan oleh seseorang yang mengajak Anda bicara. Kesimpulannya, membaca puisi bahasa inggris dapat meningkatkan kemampuan untuk mengungkapkan perasaan melalui kata-kata. Dan inilah yang menjadi bukti bahwa Anda telah bisa menggunakan bahasa inggris, lebih maju dari rekan yang lainnya. 
Pradopo(2007:314) berpendapat bahwa puisi adalah ucapan atau ekspresi tidak langsung. Puisi juga merupakan ucapan ke inti pati masalah, peristiwa, ataupun narasi (cerita, penceritaan). Makna-makna yang terdapat di dalam puisi itu sendiri dapat diperoleh melalui pembacaan, penghayatan yang sungguh-sungguh.

"membaca indah sering juga disebut membaca emosional. Dinamai demikian sebab selalu menyangkut pada hal-hal yang berkaitan dengan keindahan atau estetika yang dapat menimbulkan emosi atau perasaan dari pembaca atau pendengarnya" (Muchlisoh dkk, 1994:156)

"membaca indah sering juga disebut membaca emosional. Dinamai demikian sebab selalu menyangkut pada hal-hal yang berkaitan dengan keindahan atau estetika yang dapat menimbulkan emosi atau perasaan dari pembaca atau pendengarnya" (Muchlisoh dkk, 1994:156)

"Pembelajaran puisi bertitik berat pada siswa, mempelajari puisi agar berhasil guna (efektif dan efisien) ini berarti memerlukan perhatian dan sikap belajar yang tinggi pada siswa”. (Soebagyo Brotosejati dkk, 1999 ).

Melalui kegiatan pengabdian ini, tim pengabdian bermaksud untuk melakukan pelatihan terkait baca puisi bahasa Inggris dan bahasa Indonesia kepada para guru dan siswa di SDN 65 Pekanbaru dan SDN 63 Pekanbaru. Diharapkan setelah mengikuti kegiatan ini, para guru mampu mengajarkan baca puisi yang baik dan benar kepada para siswa.

\section{Permasalahan Mitra}

Permasalahan utama yang dihadapi oleh mitra adalah belum maksimalnya guru dalam melatih siswa dalam membaca puisi bahasa Inggris maupun bahasa Indonesia. Kompetisi yang sering mengikutsertakan siswa belum mendapatkan hasil yang memuaskan.

\section{Metode Penelitian}

Kegiatan $\mathrm{I}_{\mathrm{b}} \mathrm{m}$ dilakukan kepada guru-guru dan siswa yang berada di lingkungan SDN 65 dan 63 Pekanbaru. Peserta yang akan mengikuti kegiatan ini 40 orang terdiri dari 4 orang Guru dan 36 siswa perwakilan dari kedua sekolah tersebut. Siswa yang akan mengikuti kegiatan ini adalah perwakilan kelas IV sampai dengan kelas VI, dan 
dalam rangka mencapaai tujuan kegiatan maka akan dilakukan pre-test dan post-test. Pelaksanaan kegiatan meliputi ceramah dan praktek dengan beberapa tahap sebagai berikut.

\section{Pengenalan Puisi}

Pada tahap ini, tim melakukan transfer informasi mengenai puisi. Pada tahap ini tim memberikan pengenalan puisi dan. Materi yang disampaikan pada tahap ini adalah:

- Jenis-jenis puisi

- Pentingnya puisi bagi dunia pendidikan

Peralatan yang dibutuhkan pada tahap ini adalah:

- $\quad$ Papan tulis

- $\quad$ Power Point

2. Pelatihan baca puisi

Pada tahap ini, tim melakukan transfer informasi mengenai proses pembacaan puisi dari awal sampai akhir. Materi yang disampaikan pada tahap ini adalah:

- Penjelasan

- Praktek

Peralatan yang dibutuhkan pada tahap ini adalah:

- Papan tulis

- Laptop

\section{Pelatihan memahami makna puisi}

Pada tahap ini, tim melakukan transfer informasi mengenai makna denotasi dan konotasi, smbol dan gaya bahasa.

Peralaan yang dibutuhkan pada tahap ini adalah:

1. Papan tulis

2. Kertas 


\section{Hasil}

Membaca puisi perlu menggunakan strategi yang baik dan jitu, karena pembacaan dengan strategi yang tepat akan memberikan efek penerimaan yang menarik bagi pembaca. Jika proses membaca puisi kurang menraik atau dibaca dengan asal-asalan maka pendengar juga kurang tertarik mendengarkannya, sehingga pesan yang hendak disampaikan tidak tersampaikan dengan baik. Pengabdian masyarakat "Strategi baca puisi Inggris dan Indonesia di SDN 65 Pekanbaru dan SDN 63 Pekanbaru" yang dilaksanakan di Sekolah Dasar Negeri 65 Pekanbaru, beralamat di Jalan Pesisir Gang Natuna No. 1 Kelurahan Sri Meranti, Rumbai telah berjalan dengan baik dan mendapatkan respn sangat positif baik dari para peserta maupun dari pihak sekolah. Pengabdian ini menghasilkan beberapa hal:

1. Pelatihan strategi baca puisi Inggris dan Indonesia

2. Praktek baca puisi

3. Diskusi

4. Strategi baca puisi Inggris dan Indonesia yang tepat

\section{E. Pembahasan}

1. Pelatihan strategi baca puisi Indonesia

Peserta pelatihan terdiri dari guru dan siswa perwakilan dari Sekolah Dasar Negeri 65 Pekanbaru dan Sekolah Dasar 63 Pekanbaru. Dalam pelatihan ini, para peserta diberikan strategi-strategi membaca puisi yang benar. Pelatihan diawali dengan mendengarkan pembacaan puisi dari para siswa dari kedua Sekolah Dasar tersebut, termasuk guru bahasa Indonesia mereka. Pada saat peneliti meminta mereka membaca puisi, mereka merasa malumalu tetapi dengan sedkit dimotivasi dan dorongan maka mereka akhirnya membaca puisi dihadapan peserta lainnya. Puisi yang dibaca adalah puisi pahlawan. Pilihan puisi ini sesuai 
dengan permintaan kedua sekolah. Alasan mereka karena puisi-puisi tersebut sering dipertandingkan oleh Dinas Pendidikan.

Langkah kedua yang diberikan adalah penjelasan mengenai strategi membaca puisi:

1. Latihan pernafasan

Pada awal kegiatan para siswa membaca puisi tanpa memperhatikan dan memperhitungkan pernafasan yang benar pada saat membaca puisi. Ada diantara para peserta yang terengah-engah dan terkesan ingin cepat-cepat selesai. Peserta kemudian disarankan agar pada saat membaca puisi mereka tidak buru-butu dan tau kapan harus menggunakan nafas tenggorokan dan kapan dengan perut.

2. Latihan vocal

Para peserta diberikan materi cara membaca dengan lantang dan lepas tanpa ada beban. Huruf-huruf yang dihasilkan harus tuntas dan jelas. Peneliti menyampaikan bahwa membaca puisi laksna membaca ayat suci Al-Qur'an mestilah jelas sehingga tida merusak maknanya. Awalnya peserta banyak yang tidak tuntas dalam melafalkan huruf, seperti "a" kedengarannya "e" atau "ae"

3. Intonasi

Membaca puisi akan terasa enak ketika dengan menggunakan intonasi yang tepat juga. Peneliti menjelaskan kepada peserta kapan sebuah kata dibaca tinggi rendah, mendayu-dayu dan bahkan sedih. Karena pada hakekatnya membaca puisi adalah seperti bercerita, mestilah jelas iramanya, hal ini juga berhubungan dengan keindahan gaya bercerita. 


\section{Ekspresi}

Dalam Pelatihan ini peneliti juga menjelaskan bahwa ekspresi sangat penting pada saat membaca puisi. Denngan ekspresi yang tepat pendengar akan larut dan menkmati puisi kata demi kata.

5. Mengasah mental

Para siswa yang mengikuti pelatihan sebenarnya sangat berbakat ddan berminat menjadi pembaca puisi yang profesional tetapi mereka masih harus di drong-dorong dan ddiberikan semangat agar mau membaca. Oleh karena itu, dalam pelatihan tersebut, peneliti juga menyampaikan pentingnya mengasah mental dan rasa percaya diri.

6. Memahami

Daam pelatihan terebut, peneliti juga menyampaikan agar sebelum membaca puisi, sebaiknya peserta membaca dahulu puisi secara berulang-ulang dan memahami maksudnya, sehingga pada saat membacanya akan menikmati dan menjiwainya. Jika mereka tidak faham pada maksud puisi itu, peneliti menyarankan agar mereka bertanya kepada guru atau siapa saja yang paham dengan maksud puisi itu.

\section{F. Kesimpulan}

Membaca puisi yang baik dan benar tidak semudah yang dibayangkan, tetapi dengan bersungguh-sungguh maka banyak orang dapat melakukannya. Kegiatan baca puisi di sekolah menguntungkan pihak sekolah dan juga siswa yang memiliki bakat dalam membaca dan menikmati puisi. Siswa juga semakin mencintai dan memahami betapa pentingnya puisi dalm kehidupan.

Baca puisi bahasa Inggris juga dapat meningkatkan kecintaan siswa dalam belajar bahasa Inggris. Melaui baca puisi siswa juga belajar berbagai kosa kata bahasa Inggris dan 
cara pengucapan yang benar. Sama halnya dengan membaca puisi bahasa Indonesia, baca puisi bahasa Inggris juga memerlukan strategi yang tepat. Dalam pelatihan yang telah dilaksanakan, para siswa dan guru peserta kegiatan memperoleh pengetahuan tentang strategi dan cara membaca puisi bahasa Inggris.

\section{G. Saran}

Kegiatan pengabdian ini masih belum sempurna. Jika kegitan ini dilakukan secara konsisten dalam rentang waktu yang lebih lama, maka luarannya akan lebih baik, tetapi padatnya jadwal sekolah tidak bisa peneliti paksanakan untuk mengadakan kegiatan ini lebih lama lagi. Kegiatan ini sangat bermanfaat bagi guru dan siswa, tidak hanya untuk mempersiapkan diri sebelum mengiktui kompetisi tetapi juga memperkaya kemampuan siswa dalam bidang perpuisisan. Di samping itu, siswa juga merasa terhibur dan mendapatkan suasana yang baru. Pengabdian terkait perpuisian masih perlu dilanjutkan. Para peneliti lain juga dapat melaksanakan kegiatan-kegitan sejenis dengan topik yang berbeda.

\section{H. DAFTAR PUSTAKA}

Aufderheide, P. 2007. Documentary Film: a Very short introduction. New York: Oxford University Press.

Brotsejati, Subagyo. dkk. 1999. Materi Penataran Sistem Pembinaan Profesional. Jakarta : Departemen Pendidikan Nasional.

Harefa, A. (2002). Sekolah Saja Tidak Pernah Cukup. Jakarta: Gramedia Pustaka Utama. https://id.wikipedia.org/wiki/YouTube.

Ludiro, M. 2011. Pembuatan Film Dokumenter Wisata Pantai dan Goa di Pacitan Jawa Timur. Yogyakarta: STMIK Amikom.

Laudon, K., \& Laudon, J. (2008). Sistem Informasi Manajemen. Jakarta: Penerbit Salemba Empat.

Muchlisoh. dkk. 1994. Modul Pendidikan Bahasa Indonesia 3 DII. Jakarta : Departemen Pendidikan Nasional Purwanto, Ngalimin. 1997. Psikologi Pendidikan. Bandung : Remaja Rosdakarya. 
Mulyana, Agus. dkk. 2008. Belajar sambil Mengajar: Menghadapi perubahan sosial untuk pengelolaan sumberdaya alam. Bogor: CIFOR.

Nida, Eugene A. 1963. Morphology: the Descriptive Analysis of Words. New York: The University of Michigan Press.

Nura'ini Umri, Indriyani. 2008. Buku Sekolah Elektronik Bahasa Indonesia Untuk SD Kelas V. Jakarta. Pusat Perbukuan Departemen Pendidikan Nasional.

Pradopo, Rachmad Djoko. 1987. Pengkajian Puisi. Yogyakarta: Gadjahmada University Press.

Pradopo, Rahmat Djoko. 1994. Stilistika dalam Buletin Humaniora No.1 tahun 1994.Yogyakarta: Fakultas Sastra UGM. 